\title{
Technology Evaluation Practices in Universities' Technology Transfer Offices
}

\author{
A. Rocha ${ }^{1}$, F. Romero ${ }^{1}$ \\ ${ }^{1}$ Department of Production and Systems Engineering, University of Minho, Guimarães, Portugal \\ (fromero@dps.uminho.pt)
}

\begin{abstract}
Technology evaluation and licensing by universities has increased in recent years, stimulated by specific policies that have encouraged quantitative as well as qualitative changes in technology transfer from universities. This paper makes a review of the concepts and practices that are behind technology evaluation and licensing by universities. The literature on this subject is fragmented and dispersed, and the main objective and contribution of this paper is to provide an integrated and comprehensive overview of the concepts and practices on the subject. A conceptual order is generated, allowing the reader to identify concepts and practices, and to easily situate them in terms of their position in the chain of events that constitute the process of technology evaluation and licensing by universities.
\end{abstract}

Keywords - Technology evaluation and licensing, technology transfer, technology transfer units, universities

\section{INTRODUCTION}

Technology evaluation and licensing by universities allows for the conjugation of research results and their practical application, and to potentiate the relation between university and industry, joining together the characteristics of an invention and the needs of the market. In this paper an overview of the literature is made, highlighting the most important steps of the process of technology transfer from the universities to industry and their practical implications. The integration of the literature is made by assuming a sequence in the process of technology transfer. The sequence starts with the decision to protect, or not, an invention, it goes through the efforts for publicizing the technology portfolio and the search for a licensee, it explores the different techniques for technology evaluation and it ends with the possible payment modes implicit in a license agreement.

\section{THE UNIVERSITIES' TECHNOLOGY TRANSFER UNITS: A ORGANIZATIONAL MECHANISM FOR THE PROCESS OF TECHNOLOGY TRANSFER}

Technology transfer units (TTUs) have the aim of evaluating, protecting and supporting researchers in their efforts to obtain resources and to commercialize technology [1].

The communication of research results triggers a process of evaluation and definition of the strategy of protection and commercialization of the invention, which allows the matching of the invention characteristics with the firms development needs. Since the first communication until the association of an invention with a commercialization path, the TTUs assume principles and proceedings of technology valuation that determine the methods and practices of evaluation and licensing of technology, and that conditions the selectivity level of each university at the moment of protection and territorial expansion of the rights over an invention. It is with the aim of better understanding these principles and proceedings that the following subsections will present an integrated review of the literature.

\section{THE LEVEL OF SELECTIVITY IN THE PROTECTION OF INVENTIONS}

The question of selectivity in the process of invention protection is important. The number of registered patents does not reflect the impact that a university has on the economy, and the number of patents, on its own, does not describe the nature of the inventions nor their commercial impact [2]. Selectivity in the process of submission of patent applications made by the TTUs has a major impact on its performance [3]. The decision to patent must be influenced by the market potential of the invention and not by its scientific merit, nor by the will of the inventor. The largest the technology portfolio, the more are the resources necessary to manage them, and eventually there may be a need to concentrate commercialization efforts on a reduced number of technologies. Due to the high costs of maintaining a patent portfolio, strategic patenting is one of the most important tasks of the TTUs [4].

Having made the decision to protect and commercialize an invention, there is now the need to define a strategy of technology diffusion in order to obtain license agreements. The next section addresses this issue.

\section{THE ORIGIN OF THE LICENSING AGREEMENTS}

To transfer a technology it is necessary to find a window of opportunity [5]. An important factor that is necessary to preview the right timing for the introduction of a technology is related to its development stage and with the firm's product replacement cycles [6]. The smaller the introduction costs, and the better the technology adequacy to the firm's needs, the larger is the invention value and the probability of licensing it.

With the aim of opening it, and take full advantage of the window of opportunity, a strategy of identification of firms with capacity and interest in licensing the technology must be adopted, coupled with the definition of a strategy to communicate and publicize the invention value proposition. The next section will address that issue. 


\section{IDENTIFICATION OF LICENSEE FIRMS}

The strategy for identification of firms must include, in addition to the market and technology description, the identification of the competencies and resources which are necessary to its development and commercialization.

It is necessary to determine what are the intellectual property rights which are required for the technology to function, integrated in a product, or in a larger platform [7], what is the knowledge that must be transferred to the firms, and to assess if the firms are able to absorb it. It is necessary to understand how the technology fits within the firms' technology space, so that an alignment is achieved.

The decision to license is associated with the firms' perception of risk on an investment. Small firms and startups are the ones that are willing to assume larger risks [6], and more experimentation to test what might work. Large firms have more pre-established compromises and are less flexible in the adoption of new technologies. Established enterprises have a preference for incremental technologies [8] that adds something new to an existing invention or that alters its design. Smaller firms are more willing to adopt technologies in initial development stages [8] [9], or technologies that present disruptive characteristics that allow for the development of new generation of products based on different scientific domains.

Independently of the firms' maturity and size, the adoption of the technology is dependent of their strategic orientation [10]. Firms, whose growth is more dependent on new product and processes, continuously seek new technology and business opportunities, and they are potential licensees to look for. The task of identification of firms with capacity and interest in licensing requires a systematic work of technology and potential partner analysis, as well as the identification of possible sources of financing. Ideally, a good partner for the introduction and development of the technology should have adequate technological capacity and competences; have the necessary networks and resources; have a significant client base and a strong brand; be able to address the markets that are relevant; have a risk taking attitude.

Having clarified the profile of the firms to be contacted, the next step is the communication and publicity of the technology, an issue to be addressed in the next section.

\section{PUBLICITATION}

The origin of licensing agreements is associated with the size and quality of the TTUs and researchers networks - "one's worth can be approximated by the size (and quality) of one's network" [11]. TTUs acknowledge that the inventors are the most important source of contacts for licensing [12], and they are the primary source in firms' identification [13] [1]. Inventors can be a "one stop source of market information" [7], and the inventors direct contact with firms is the most important factor in the establishment of licensing agreements, and the second most important one is the marketing effort made by the TTUs. Agreements obtained by inventors are made predominantly with large enterprises, while the agreements obtained by the TTUs are made predominantly with smaller firms. The explanation seems to be related with the fact that smaller firms have fewer resources to invest in technology watch and are more receptive to the information provided by the TTUs communication channels. Investment in direct marketing with small firms may prove more useful than marketing directed to large firms [14].

\section{OBSTACLES TO TECHNOLOGY TRANSFER}

Some of the obstacles are the TTUs lack of experience in the management of evaluation and licensing processes [15], the location of the university in a not highly technologically developed region, the universities lack of a clearly defined mission in supporting technology transfer [16], the availability of financial resources [17], the reduced number of technology transfer personnel [18], the brand value of the institution and the lack of previous connections with industry [19]. Other factors associated with the universities technology transfer practices include information deficiencies, insufficient technology watch, deficient marketing strategies, difficulties in finding business partners with adequate capacities and resources for technology further development, the lack of entrepreneurial initiative, the inability to determine the technologies investment risk, and the lack of administrative support in preparing financial applications and project management [20].

The early-stage of technology development, the inexistence of a final product, uncertainty in cost estimates or profit margins, the lack of TTUs commitment in a line of business, and the mismatch between technology specifications and industry requirements [21] constitute additional identified barriers to technology transfer.

\section{EVALUATION METHODS}

Technology evaluation and the assessment of its commercialization potential is a transversal task that sweeps across the process of technology transfer, allowing some of the referred obstacles to be surpassed. Since the invention disclosure until the patent license or assignment, several evaluation methods are used. The most common methods are: Pre-defined evaluation models and matrices; Comparable license agreements and the observation of royalties practiced in industry; Evaluation based on development costs; Discounted cashflow methods; The 25\% rule; Real options and Monte Carlo simulation methods; Patent auctions. In the following sections we address each method separately.

\section{PRE-DEFINED EVALUATION MODELS AND MATRICES}


Methods based on checklists and in pre-defined evaluation models speed up the process and facilitate the consideration of multiple dimensions of the invention, from the intrinsic quality of the technology to the market potential and profitability, constituting the most widely used instruments in the evaluation of invention disclosures. Some of those instruments are: COAP Commercial Opportunities Appraisal Process, developed by Warwick University; Rapidscreen, a process supported by a web service; IPscore 2.2, developed by the European Patent Office; Commercialization Quicklook Assessment, developed by Texas University.

\section{COMPARABLE LICENSE AGREEMENTS AND THE OBSERVATION OF ROYALTIES PRACTICED IN INDUSTRY}

Analysis of previous licensing agreements and the observation of royalties practiced in the industry (royalty standards) may provide guidance to define and defend the payments structure and its value during the negotiation of a technology transfer agreement [22]. The search for comparable license agreements and royalty standards is an effort that usually pays off [23], although the specificity of each technology does not call for standard agreements. But it is important that TTUs build and maintain reference agreements portfolios which can be used if needed. Databases and publication with royalty standards and licensing agreements are a good source of information.

\section{EVALUATION BASED ON DEVELOPMENT COSTS}

Evaluation based on development costs is rarely a base on which firms negotiate license agreements. The market value is a more appropriate metric for evaluating a technology [22]. However, the evaluation based on development costs can be used before the start of a project as a way to estimate future costs and future investment.

\section{DISCOUNTED CASH-FLOW METHOD}

The discounted cash-flow method is widely used by organizations who deal and license technology [24]. The calculus of the discounted cash-flows is important for business profitability discussions and to provide a basis for setting up royalties and other payments value.

\section{THE 25\% RULE}

The $25 \%$ rule is usually applied to the EBIT earnings before interest and taxes [24], suggesting that the licensee pays a fee equivalent to $25 \%$ of the invention contribution to the operational results obtained by the product that embodies the technology. The $25 \%$ rule divides the value of a technology in four parts: the creation of the invention, the preparation of the invention for industrial reproduction, industrial reproduction, and the sale of the invention, per se, or incorporated in a larger product. The rule is a starting point, adopted by licensors and firms, for royalties' negotiation, thanks to its simplicity, intuitive reasonability and acceptance by many authors [25] [24] [26] [22].

\section{REAL OPTIONS AND MONTE CARLO SIMULATION METHODS}

The real option method allows the separate evaluation of all the assumptions involved in a cash-flow projection, each assumption having a different level of uncertainty for which different risk-adjusted hurdle rates are defined [27]. Used only by some firms, and Monte Carlo methods used more than real options methods.

\section{PATENT AUCTIONS}

Auctions are a quicker way of commercializing patents, provided they are of high quality. However, auctions require a considerable organization and public citation effort [28] and it is not easy to have several bids for just one technology.

\section{THE ARTICULATION BETWEEN THE METHODS}

The methods presented above are used in different stages of the evaluation process. In a first stage, preparatory for the submission of a patent application, databases of patents are extensively used, in order to understand the invention and the state of the art related to it. The scoring matrices and the rapid report models are used to understand the market potential of the invention.

In a second stage, e.g., when there is a firm that has already demonstrated its interest in the invention, the technology transfer units tend to recur to comparable agreements, royalty standards, and sometimes DCF and the $25 \%$ rule.

Simultaneously with these two stages, the TTUs network of contacts is activated, in order to obtain technical and market counseling.

In general, the systematic work done previously, based on the various evaluation methods, will support the draft of an agreement that is seen positively by both parties, and a balanced distribution of the gains will be achieved. To understand the process of negotiation there is the need to address the possible modes of payment. The next section addresses that issue.

\section{TYPES OF PAYMENT USED IN LICENSING AGREEMENTS}

The definition of the payment structure must consider the different dispositions that influence the value of the technology transfer agreement. Some of those are:

- At the technology level: the invention scope, territorial rights and protection length, the level of exclusivity conceded to reproduce, modify, make further R\&D or to develop new products based on 
the invention, the stage of technology development, the level of complexity and the skills required to use it, its robustness to operate in different environments, its friendly use, easy and intuitive reproduction and packaging, the number of technologies that must be integrated with the invention to obtain a full commercial product, the possibility of mass production, the compatibility with existing systems, the risks and the costs inherent to future developments, and its social and environmental impact;

- At the market level: the present and emergent competitive technologies, the technology strategic importance, the differentiated applications resulting from the invention and the industries envisaged, the applications market size and its growth rate, the strength of existing firms and brands, the marketing, distribution and sales complexity, and the applications life cycle.

These are some dispositions which affect the payments value, but there are other dispositions that also deserve attention, such as the rights over the improvements made with or on the technology, the possibility of sub-licensing, the payment of patent fees in several countries, the agreement length, and the exclusivity of rights granted, the inclusion of technical services, the provision of equipment or other resources from the part of the university or the firm, the existence of projects and competing R\&D teams, the value of the royalties practiced in the industry and the potential gains from the technology commercialization.

Due to lack of space, payment modalities will not be addressed in detail here, only reference to its name. They can be divided in fourteen categories: single lump sum payment or paid-up; fixed fee per sold unit or technology utilization; earned royalties, running royalties or pure royalty licenses - royalties based on a percentage of sales or technology utilizations; up-front payment or up-front fee; minimum (annual) cash payment - minimums or minimum royalties or license maintenance fees; stage payments or milestone payments; option agreements and options payments; royalty adjustments; deferred royalty calculations; late payment penalties; termination fees or kill fees; sub-licensing payments; equity payments; support payments. An agreement may include multiple modes of payments and the above categories are not exhaustive.

\section{EARNINGS DISTRIBUTION WITHIN THE UNIVERSITY}

Each university has its own rules or set of principles that define how the gains from licensing agreements is distributed within the university actors [29]. Higher fees paid to the inventors seem to be positively related to the number of inventions, to the financial return of the licenses and in the attraction of abler researchers [30]. Universities tend to pay larger percentages to inventors that take the initiative of creating their own spin-off firm
[31]. Typically the TTUs receive a percentage of $10 \%$ to $25 \%$ and the university tends to subsidize directly the activities of the TTU during several years, until it becomes self-sufficient [1]. Many years can pass before self-sufficiency is attained, and the TTUs must reach a balance between the resources available and what they can protect. As a rule of thumb, only one in ten inventions disclosures is patentable, and only one in ten patents is licensable. Evaluation practices are thus essential in the process of decision making regarding patents and in the marketing and licensing of inventions.

\section{MAPPING THE EVALUATION PROCESS AND SPECIFYING PROCEDURES AND TECHNIQUES}

Having in mind the aim of understanding and improving the information and knowledge about methods and strategies of evaluation and licensing of technologies by the universities, this paper aimed at reviewing the scattered and disparate perspectives of the literature, highlighting the main processes and techniques used in the process by units of technology transfer within the universities. The main ideas and areas of concern for the process of technology transfer are now grouped according to the main concepts of the paper. These ideas reflect an order in the chain of events implicit in the process of technology transfer from the universities.

Selectivity in patent protection:

- Different degrees of selectivity in terms of patent protection are assumed.

- The size of the patent portfolio is not directly related to the number of license agreements;

Origin of technology transfer agreements:

- Informal networks;

- Contacts that inventors have with firms;

- Firms that commercialize similar products;

- Demonstrable products reduce the perception of risk;

- Technology communication and diffusion strategies.

Obstacles to technology transfer:

- Difficulty in finding partners with adequate technological and marketing capacities;

- Cost uncertainty

- Stage of development of the technology

- Time required to obtain products with required specifications.

Technology evaluation:

- Checklists and pre-defined models of evaluation are the most utilized methods of evaluation.

- Use of previous agreements and cash-flows projections.

- Techniques differ depending on the stage of the process.

- Evaluation is runs across the whole process.

Payment structure:

- Lump sums and running royalties are frequently included in technology transfer agreements.

- Others modes serve as incentives or guarantees.

Distribution of earnings from technology transfer agreements: 
- Allocation of revenues to the inventors differs from university to university.

- Specification of the allocation of revenues to the TTUs.

\section{REFERENCES}

[1] T. Young, "Establishing a Technology Transfer Office," in Intellectual Property Management in Health and Agricultural Innovation: A Handbook of Best Practices A. Krattiger, R. T. Mahoney, L. Nelsen, J. A. Thomson, A. B. Bennett, K. Satyanarayana, G. D. Graff, C. Fernandez, and S. P. Kowalski, Eds. Oxford and Davis: MIHR and PIPRA, 2007.

[2] A. Agrawal and R. Henderson, "Putting patents in context: exploring knowledge transfer from MIT," Management Science, vol. 48, no. 1, pp. 44-60, 2002

[3] J. Powers and P. McDougall, "University start-up formation and technology licensing with firms that go public: a resource-based view of academic entrepreneurship," Journal of Business Venturing, vol. 20, no. 3, pp. 291-311, 2005.

[4] Z. Xu, M. E. Parry, and M. Song, "The impact of technology transfer office characteristics on university invention disclosure," IEEE Transactions on Engineering Management, vol. 58, no. 2, pp. 212-227, 2011.

[5] D. F. Abell, Defining the Business: The Starting Point of Strategic Planning. London: Prentice-Hall, 1980.

[6] S. Speser, The art \& science of technology Transfer. New Jersey: John Wiley \& Sons, 2006.

[7] A. C. di Sante, "The role of the inventor in the technology transfer process," in Intellectual Property Management in Health and Agricultural Innovation: A Handbook of Best Practices, A. Krattiger, R. T. Mahoney, L. Nelsen, J. A. Thomson, A. B. Bennett, K. Satyanarayana, G. D. Graff, C. Fernandez, and S. P. Kowalski, Eds. Oxford and Davis: MIHR and PIPRA, 2007.

[8] S. Shane, "Encouraging university entrepreneurship? The effect of the Bayh-Dole act on university patenting in the United States," Journal of Business Venturing, vol. 19, no. 1, pp. 127-151, 2004.

[9] J. G. Thursby, R. Jensen, and M. C. Thursby, "Objectives, Characteristics and Outcomes of University Licensing: A Survey of Major U.S. Universities," The Journal of Technology Transfer, vol. 26, no. 1, pp. 59-72, 2001.

[10] R. Miles, S. C., and M. A., "Organizational Strategy, Structure and Process," The Academy of Management Review, vol. 3, no. 3, pp. 546-562, 1978.

[11] P. Kolchinsky, "The entrepreneur's guide to a biotech startup," 2004.

[12] D. Hsu and D. Bernstein, "Managing the university technology licensing process: Findings from case studies," Journal of the Association of University Technology Managers, vol. 91-33, 1997.

[13] J. G. Thursby and M. C. Thursby, "Are Faculty Critical? Their Role in University-Industry Licensing," Contemporary Economic Policy, vol. 22, no. 2, pp. 162178, 2004.

[14] V. Ramakrishnan, J. Chen, and K. Balakrishnan, "Effective strategies for marketing biomedical inventions: Lessons learnt from NIH license leads," Journal of Medical Marketing, vol. 5, no. 4, pp. 342-352, 2005.

[15] S. Collins and H. Wakoh, "Universities and technology transfer in Japan: recent reforms in historical perspective," Journal of Technology Transfer, vol. 25, no. 2, pp. 213222,2000
[16] J. Friedman and J. Silberman, "University Technology Transfer: Do Incentives, Management, and Location Matter?," Journal of Technology Transfer, vol. 2817-30, 2003.

[17] J. Dodds and S. Somersalo, "Practical Considerations for the Establishment of a Technology Transfer Office," in Intellectual Property Management in Health and Agricultural Innovation: A Handbook of Best Practices, A. Krattiger, R. T. Mahoney, L. Nelsen, J. A. Thomson, A. B. Bennett, K. Satyanarayana, G. D. Graff, C. Fernandez, and S. P. Kowalski, Eds. Oxford and Davis: MIHR and PIPRA, 2007.

[18] P. M. Swamidass and V. Vulasa, "Why university inventions rarely produce income? Bottlenecks in university technology transfer," Journal of Technology Transfer, vol. 34, no. 4, pp. 343-363, 2009.

[19] B. Harmon, A. Ardishvili, R. Cardozo, T. Elder, J. Leuthold, and J. Parshall, "Mapping the university technology transfer process," Journal of Business Venturing, vol. 12, no. 6, pp. 423-434, 1997.

[20] S. Arvanities, U. Kubli, N. Sydow, and M. Worter, "Knowledge and technology transfer (KTT) activities between universities and firms in Switzerland: the main facts," Swiss Federal Institute of Technology Zurich and Swiss Institute for Business Cycle Research 2005.

[21] R. McAdam, M. McAdam, and V. Brown, "Proof of concept processes in UK university technology transfer: an absorptive capacity perspective," $R \& D$ Management, vol. 39, no. 2, pp. 192-210, 2009.

[22] WIPO/ITC, "Exchanging value: negotiating technology licensing agreements. A training Manual.," WIPO/ITC, 2005.

[23] R. Razgaities, Valuation and Princing of TechnologyBased Intellectual Property. New Jersey: John Wiley \& Sons, 2003.

[24] J. Kemmerer and E. Jiaquing, "Profitability and royalty rates across industries: some preliminary evidence," Journal of Academy of Business and Economics, 2008.

[25] O. Grandstrand, "Fair and reasonable royalty rate determination. When is the $25 \%$ rule applicable?," Les Nouvelles 179-181, 2006.

[26] R. Parr, Royalty Rates for Licensing Intellectual Property. New Jersey: John Wiley \&Sons, 2007.

[27] I. Soares, J. Moreira, C. Pinho, and J. Couto, Decisões de Investimento. Análise Financeira de Projectos. Lisboa: Edições Sílabo, 2007.

[28] D. Tansik, K. Dakin, and J. Lindsey, Technology transfer: Financing and commercializing the high tech product or service from research to roll out. Chicago: Probus Publishing Company, 1991.

[29] N. Baldini, "Do royalties really foster university patenting activity? An answer from Italy," Technovation, vol. 30, no. 2, pp. 109-116, 2010.

[30] S. Lach and M. Schankerman, "Incentives and Invention in Universities," in National Bureau of Economic Research Working Papers, 2003.

[31] A. Lockett, M. Wright, and S. Franklin, "Technology transfer and universities spin-out strategies," Small Business Economics, vol. 20, no. 2, pp. 185-200, 2003. 